\title{
Effects of castration, $5 \alpha$-dihydrotestosterone and cyproterone acetate on enzyme activity in the mouse epididymis
}

\author{
R. K. Rastogi, M. Milone, M. Di Meglio, M. F. Caliendo and G. Chieffi \\ Institute and Museum of Zoology, University of Naples, via Mezzocannone 8, 80134 Naples, \\ Italy
}

\begin{abstract}
Summary. The influence of castration, androgen replacement therapy and cyproterone acetate on the activity of $\beta$-glucuronidase, acid and alkaline phosphatases and glucose-6-phosphate dehydrogenase was studied in the caput, corpus and cauda epididymidis of the mouse. The results add further evidence that the epididymis is not uniform but has regional differences in activity. Thus $\beta$ glucuronidase was found to be androgen-dependent only in the cauda epididymidis, whereas glucose-6-phosphate dehydrogenase was under androgenic control in the caput epididymidis. The response of alkaline and acid phosphatases to castration and to androgen replacement was different in different segments.
\end{abstract}

\section{Introduction}

It is now well known that when the spermatozoa leave the testis they are not capable of fertilizing an egg and they acquire this ability during the time they spend traversing the epididymal duct. This suggests that the epididymis provides an essential environment for the functional maturation of spermatozoa (Hamilton, 1975; Orgebin-Crist, Danzo \& Davies, 1975). Several reports have appeared which emphasize that (a) the epididymis has both absorptive as well as secretory functions, (b) it is dependent on androgens for its morphological and functional integrity, and (c) it receives androgens from the testis and from the general circulation, and also has its own steroid function (Nicander, 1970; Hamilton, 1971; Prasad, Rajalakshmi, Gupta \& Karkun, 1973; Jones, 1974; Hamilton, 1975; Ganjam \& Amann, 1976; Djøseland, Hastings \& Hansson, 1976; Rastogi, Saxena \& Iela, 1976). This understanding and a growing tendency to consider the epididymis as a target and model for studies on fertility control in the male indicate the importance of a detailed investigation of all androgen-dependent processes in this organ. To this end several morphological and biochemical parameters have been studied, for example, weight, epithelial cell height, glycolytic enzymes, $\mathrm{pH}$, inorganic cations, carnitine, glycerylphosphoryl choline, sialic acid and proteinases (Prasad, Rajalakshmi \& Reddy, 1972; Prasad et al., 1973; Brooks, 1976a, b; Nag, Sarkar \& Ghosh, 1977; Jones, 1977; Back, Glover, Shenton \& Boyd, 1977; Rastogi, 1979). The results suggested that there are structural and functional variations in the different regions of the epididymis in different species and in the epididymal response to androgen manipulations.

The present work was undertaken to study the time-related effects of castration, effects of androgen replacement therapy and of the steroidal antiandrogen, cyproterone acetate, on the activity of $\beta$-glucuronidase, acid and alkaline phosphatases and glucose-6-phosphate dehydrogenase in the mouse epididymis. 


\section{Materials and Methods}

Adult male mice $(25-30 \mathrm{~g})$ of the Swiss albino strain were caged in groups of 5 each with free access to food and water. Animals were subjected to light ether anaesthesia and castration was performed via the scrotal route. The ductuli efferentes were severed by thermocautery, the testes removed and the wound closed. Batches of 5 animals each were killed at 7, 14, 21, 28 and 42 days following castration. After 6 weeks the remaining castrated animals (total of 20 divided into 4 groups) received daily injections (s.c.) of $5 \mu \mathrm{g} 5 \alpha$-dihydrotestosterone. $50 \mu \mathrm{g} 5 \alpha$-dihydrotestosterone, $50 \mu \mathrm{g} 5 \alpha$-dihydrotestosterone $+0.5 \mathrm{mg}$ cyproterone acetate, or the maize oil vehicle. The injections were continued for 15 days before the mice were killed. Before death by overdose of ether each animal was weighed. The epididymides were quickly removed and freed of surrounding fat. The caput (head), corpus (body) and cauda (tail) segments were separated from one epididymis, weighed and homogenized in ice-cold deionized water for enzyme assay. The contralateral epididymides were fixed in Bouin's fluid and processed for routine histological examination.

Coenzymes, enzymes and substrates were obtained from Boehringer Mannhein, West Germany, or Sigma Chemical Co., St. Louis, Missouri. 5a-Dihydrotestostrone was obtained from Sigma and cyproterone acetate (1,2a-methylene-6-chlor-pregne-4,6-diene-3,20-dione-17aacetate) was a gift from Schering AG, Berlin.

Proteins were determined, in the aqueous homogenate, according to the method of Lowry, Rosebrough, Farr \& Randall (1951). Enzymes were assayed as described by Milone, Rastogi \& Iela (1975) and Milone \& Rastogi (1976). Enzyme activities were expressed as follows: acid phosphatase (EC 3.1.3.2) and alkaline phosphatase (EC 3.1.3.1) as nmol $p$-nitrophenol liberated $/ \mu \mathrm{g}$ protein $/ \mathrm{min} ; \beta$-glucuronidase (EC 3.2.1.31) as nmol phenolphthalein liberated $/ \mu \mathrm{g}$ protein/min; glucose-6-phosphate dehydrogenase (EC 1.1.1.49) as pmol NADP reduced $/ \mu \mathrm{g}$ protein $/ \mathrm{min}$.

Results were analysed for significance by Student's $t$ test (Fisher, 1954). Values of $P<0.05$ were considered significant.

\section{Results}

\section{Influence of castration (Table 1)}

Caput epididymidis. The wet weight of this segment showed a progressive decline over the 6week period of castration. In contrast, castration had no effect upon the protein content, and activity of alkaline phosphatase and $\beta$-glucuronidase. Similarly, the activity of glucose-6-phosphate dehydrogenase did not change during the first 4 weeks of castration but had decreased by the end of 6 weeks. Acid phosphatase activity increased after 1 week of castration; thereafter enzyme activity decreased and maintained the control level throughout the rest of the experiment.

Corpus epididymidis. The wet weight and the protein content decreased progressively over the 6 -week period of study reaching levels less than $25 \%$ of the control value. $\beta$-Glucuronidase activity remained largely unaffected by castration. As in the caput the acid phosphatase activity in the corpus epididymidis increased 1 week after castration, returning thereafter within the control range. Alkaline phosphatase activity increased at 1 week after castration, reached and maintained the control range during the following weeks to increase again at 6 weeks after castration. Glucose-6-phosphate dehydrogenase activity, after an initial lag of 1 week, increased over the 6-week period of study.

Cauda epididymidis. As in the other 2 segments the wet weight of the cauda epididymidis decreased progressively with time. Protein content decreased only after 4 and 6 weeks of castration. $\beta$-Glucuronidase, acid and alkaline phosphatases increased only at 2 weeks after 
Table 1. Influence of castration on the enzyme activity (see 'Materials and Methods') in the mouse epididymis

\begin{tabular}{|c|c|c|c|c|c|c|}
\hline & $\begin{array}{l}\text { Wet weight } \\
\text { (g/100 g } \\
\text { body wt) }\end{array}$ & $\begin{array}{c}\text { Protein } \\
\text { ( } \mu \mathrm{g} / \mathrm{mg} \text { wet } \\
\text { tissue) }\end{array}$ & $\beta$-Glucuronidase & $\begin{array}{c}\text { Acid } \\
\text { phosphatase }\end{array}$ & $\begin{array}{c}\text { Alkaline } \\
\text { phosphatase }\end{array}$ & $\begin{array}{c}\text { Glucose-6- } \\
\text { phosphate } \\
\text { dehydrogenase }\end{array}$ \\
\hline \multicolumn{7}{|c|}{ Caput epididymidis } \\
\hline $\begin{array}{l}\text { Intact control } \\
\text { Castrated }\end{array}$ & $0.62 \pm 0.14$ & $44 \cdot 1 \pm 17 \cdot 0$ & $5 \cdot 14 \pm 1.88$ & $2.60 \pm 0.85$ & $7.96 \pm 2.18$ & $651 \pm 203$ \\
\hline 1 week & $0.38 \pm 0.08^{*}$ & $36 \cdot 1 \pm 4 \cdot 6$ & $5.55 \pm 1.23$ & $4.92 \pm 0.47^{*}$ & $10.01 \pm 2.43$ & $663 \pm 226$ \\
\hline 2 weeks & $0.21 \pm 0.06 \dagger$ & $41.4 \pm 16.8$ & $4 \cdot 54 \pm 1 \cdot 18$ & $3.89 \pm 1.61$ & $10 \cdot 27 \pm 5.11$ & $744 \pm 284$ \\
\hline 3 weeks & $0.20 \pm 0.04 \dagger$ & $44 \cdot 8 \pm 8 \cdot 7$ & $5.06 \pm 1.52$ & $2.08 \pm 0.65$ & $7.40 \pm 4.77$ & $492 \pm 222$ \\
\hline 4 weeks & $0.21 \pm 0.05 t$ & $44 \cdot 7 \pm 6 \cdot 2$ & $3.83 \pm 1.51$ & $2.50 \pm 0.21$ & $8.91 \pm 2.90$ & $289 \pm 138$ \\
\hline 6 weeks & $0.13 \pm 0.02 \dagger$ & $31.6 \pm 7.5$ & $3.50 \pm 0.64$ & $3.03 \pm 0.91$ & $12.90 \pm 5 \cdot 70$ & $11 \pm 2 \dagger$ \\
\hline \multicolumn{7}{|c|}{ Corpus epididymidis } \\
\hline $\begin{array}{l}\text { Intact control } \\
\text { Castrated }\end{array}$ & $0.40 \pm 0.04$ & $48 \cdot 3 \pm 17 \cdot 8$ & $6.00 \pm 2.06$ & $2.55 \pm 0.55$ & $8.41 \pm 2.04$ & $589 \pm 272$ \\
\hline 1 week & $0.18 \pm 0.06 t$ & $29 \cdot 1 \pm 12 \cdot 1$ & $9.83 \pm 3.54$ & $7 \cdot 26 \pm 2 \cdot 39^{\dagger}$ & $14 \cdot 36 \pm 3 \cdot 88^{*}$ & $785 \pm 240$ \\
\hline 2 weeks & $0.16 \pm 0.05 t$ & $19 \cdot 6 \pm 6 \cdot 3^{*}$ & $9 \cdot 36 \pm 2.11$ & $4.66 \pm 1.86$ & $9.05 \pm 3.51$ & $1031 \pm 495^{*}$ \\
\hline 3 weeks & $0.15 \pm 0.06 t$ & $19.1 \pm 9.9^{*}$ & $9 \cdot 10 \pm 3.86$ & $2.31 \pm 1.23$ & $6.88 \pm 2.43$ & $1248 \pm 212 \dagger$ \\
\hline 4 weeks & $0.16 \pm 0.03 \dagger$ & $20.1 \pm 8.4^{*}$ & $9.26 \pm 2.66$ & $3.90 \pm 1.41$ & $7 \cdot 54 \pm 4.30$ & $1681 \pm 446 \dagger$ \\
\hline 6 weeks & $0.08 \pm 0.01 \dagger$ & $11.4 \pm 3.5 \dagger$ & $4.10 \pm 0.37$ & $4.70 \pm 1.41$ & $32.50 \pm 9.11 \dagger$ & $1460 \pm 153 \dagger$ \\
\hline \multicolumn{7}{|c|}{ Cauda epididymidis } \\
\hline $\begin{array}{l}\text { Intact control } \\
\text { Castrated }\end{array}$ & $0.48 \pm 0.09$ & $40 \cdot 6 \pm 8 \cdot 9$ & $5 \cdot 16 \pm 1 \cdot 37$ & $2.26 \pm 0.53$ & $6.28 \pm 2.04$ & $579 \pm 296$ \\
\hline 1 week & $0.32 \pm 0.12$ & $33.9 \pm 6.4$ & $6.47 \pm 2.59$ & $3.95 \pm 1.57$ & $12 \cdot 13 \pm 7.00$ & $430 \pm 134$ \\
\hline 2 weeks & $0.27 \pm 0.05^{*}$ & $28.6 \pm 9.5$ & $9 \cdot 17 \pm 2.23^{*}$ & $4.38 \pm 0.50^{*}$ & $12 \cdot 31 \pm 2 \cdot 44^{*}$ & $600 \pm 185$ \\
\hline 3 weeks & $0.17 \pm 0.07 \dagger$ & $31.2 \pm 7.9$ & $7 \cdot 15 \pm 2.87$ & $2.88 \pm 0.54$ & $5.38 \pm 1.56$ & $471+100$ \\
\hline 4 weeks & $0.20 \pm 0.04 \dagger$ & $26.3 \pm 7.8$ & $4.70 \pm 1.29$ & $2.98 \pm 0.81$ & $5.56 \pm 2.73$ & $472 \pm 148$ \\
\hline 6 weeks & $0.11 \pm 0.02 \dagger$ & $19.4 \pm 3.8 \dagger$ & $2.37 \pm 0.26 \dagger$ & $3.27 \pm 0.58$ & $8.07 \pm 2.83$ & $520 \pm 140$ \\
\hline
\end{tabular}

Values are mean \pm s.e.m. for 5 mice/group.

Significantly different from intact controls, ${ }^{*} 0.02<P<0.05 ; \dagger P<0.01$.

castration, declining thereafter to reach the control level, except for a further decline in the activity of $\beta$-glucuronidase after 6 weeks. The activity of glucose- 6 -phosphate dehydrogenase remained unchanged over the 6 weeks of castration.

\section{Response to androgen replacement therapy and cyproterone acetate (Table 2)}

Caput epididymidis. The wet weight and glucose-6-phosphate dehydrogenase activity were significantly increased at $5 \mu \mathrm{g}$ androgen/day; there was a further increase at the higher dose (50 $\mu \mathrm{g} /$ day). Protein content was equally stimulated at both doses. $\beta$-Glucuronidase was stimulated at the higher dose only. Cyproterone acetate inhibited the stimulation caused by the androgen. Neither steroid affected the activity of acid and alkaline phosphatases.

Corpus epididymidis. The wet weight increased only with the higher dose of androgen. The activity of acid and alkaline phosphatases was stimulated by the higher dose but inhibited by the simultaneous administration of the antiandrogen. Glucose-6-phosphate dehydrogenase was only slightly stimulated at the higher dose of the androgen. The response of protein and $\beta$ glucuronidase to these treatments was similar to that in the caput epididymidis.

Cauda epididymidis. The response of wet weight, protein content, $\beta$-glucuronidase, and acid and alkaline phosphatases to androgen replacement and antiandrogen was similar to that observed in the caput epididymidis. Glucose-6-phosphate dehydrogenase activity, on the other hand, was greatly decreased after androgen therapy and further decreased by the simultaneous administration of cyproterone acetate.

\section{Histology}

Histological examination of the different segments of the epididymis of different experimental groups showed that castration caused a rapid disappearance of spermatozoa from the lumen of 
Table 2. Effects of $5 \alpha$-dihydrotestosterone (DHT) and cyproterone acetate (CA: $0.5 \mathrm{mg}$ ) on the enzyme activity (see 'Materials and Methods') in the epididymides of mice castrated for 6 weeks before treatment

for 15 days

\begin{tabular}{|c|c|c|c|c|c|c|}
\hline Treatments & $\begin{array}{l}\text { Wet weight } \\
\text { (g/100 g } \\
\text { body wt) }\end{array}$ & $\begin{array}{c}\text { Protein } \\
(\mu \mathrm{g} / \mathrm{mg} \text { wet } \\
\text { tissue })\end{array}$ & $\beta$-Glucuronidase & $\begin{array}{c}\text { Acid } \\
\text { phosphatase }\end{array}$ & $\begin{array}{c}\text { Alkaline } \\
\text { phosphatase }\end{array}$ & $\begin{array}{c}\text { Glucose-6- } \\
\text { phosphate } \\
\text { dehydrogenase }\end{array}$ \\
\hline \multicolumn{7}{|l|}{ Caput epididymidis } \\
\hline Castrated control & $0.18 \pm 0.03$ & $46.8 \pm 6.8$ & $4.44 \pm 0.42$ & $3.23 \pm 0.59$ & $9.60 \pm 0.41$ & $16 \pm 3$ \\
\hline $5 \mu \mathrm{g} \mathrm{DHT}$ & $0.26 \pm 0.02 \dagger$ & $78.8 \pm 7.2 \dagger$ & $3.85 \pm 0.21$ & $2.70 \pm 0.35$ & $7.73 \pm 1.00$ & $117 \pm 21 \dagger$ \\
\hline $50 \mu \mathrm{g}$ DHT & $0.43 \pm 0.07 \dagger$ & $73.5 \pm 8.6 \dagger$ & $6.21 \pm 0.19 \dagger$ & $4.32 \pm 0.58$ & $8.00 \pm 1.41$ & $621 \pm 72 \dagger$ \\
\hline $50 \mu \mathrm{g} \mathrm{DHT}+\mathrm{CA}$ & $0.17 \pm 0.02$ & $55.9 \pm 4.9$ & $1.56 \pm 0.14 \dagger$ & $3.99 \pm 0.91$ & $7.51 \pm 1.92$ & $13 \pm 3$ \\
\hline \multicolumn{7}{|l|}{ Corpus epididymidis } \\
\hline Castrated control & $0.10 \pm 0.02$ & $20 \cdot 6 \pm 5.6$ & $3.87 \pm 0.70$ & $3.64 \pm 0.32$ & $7.97 \pm 0.29$ & $1300 \pm 351$ \\
\hline $5 \mu \mathrm{g}$ DHT & $0.11 \pm 0.02$ & $73.1 \pm 11.5 \dagger$ & $3 \cdot 30 \pm 1 \cdot 46$ & $3.77 \pm 0.64$ & $9 \cdot 10 \pm 1 \cdot 30$ & $1690 \pm 280$ \\
\hline $50 \mu \mathrm{g} \mathrm{DHT}$ & $0.30 \pm 0.05 \dagger$ & $79.2 \pm 10.9 \dagger$ & $9.93 \pm 2.28 \dagger$ & $11.94 \pm 2.74 \dagger$ & $21.54 \pm 2.12 \dagger$ & $213 \pm 570^{*}$ \\
\hline $50 \mu \mathrm{g} D H T+C A$ & $0.08 \pm 0.01$ & $54 \cdot 2 \pm 6 \cdot 5 \dagger$ & $2 \cdot 18 \pm 0.39^{*}$ & $2 \cdot 82 \pm 1 \cdot 32$ & $9 \cdot 19 \pm 6 \cdot 71$ & $646 \pm 124 \dagger$ \\
\hline \multicolumn{7}{|l|}{ Cauda epididymidis } \\
\hline Castrated control & $0.17 \pm 0.01$ & $21 \cdot 5 \pm 1 \cdot 5$ & $2.18 \pm 0.37$ & $2.97 \pm 0.25$ & $4.90 \pm 1.04$ & $648 \pm 151$ \\
\hline $5 \mu \mathrm{g}$ DHT & $0.25 \pm 0.02^{*}$ & $66.9 \pm 12.4^{\dagger}$ & $2.65 \pm 0.63$ & $2.90 \pm 0.56$ & $6.50 \pm 1.33$ & $180 \pm 37 \dagger$ \\
\hline $50 \mu \mathrm{g} \mathrm{DHT}$ & $0.45 \pm 0.10 \dagger$ & $66.7 \pm 14.8^{\dagger}$ & $6.19 \pm 0.71 \dagger$ & $3.72 \pm 0.82$ & $6.75 \pm 1.89$ & $141 \pm 11 \dagger$ \\
\hline $50 \mu \mathrm{g} \mathrm{DHT}+\mathrm{CA}$ & $0.14 \pm 0.01$ & $50.9 \pm 5.2 \dagger$ & $2.96 \pm 0.58$ & $2.53 \pm 1.01$ & $7 \cdot 56 \pm 3 \cdot 35$ & $10 \pm 2 \dagger$ \\
\hline
\end{tabular}

Values are mean \pm s.e.m. for 5 mice/group.

Significantly different from untreated castrated control; ${ }^{*} 0.02<P<0.05 ; \uparrow P<0.01$.

the different segments. The lumen diameter and the height of the epithelium greatly decreased. These regressive changes were successfully reversed by the androgen replacement therapy, but the androgen-dependent recovery was totally inhibited by the antiandrogen.

\section{Discussion}

The results presented in this study clearly indicate that there are differences in the response of the same enzymes in different segments of the epididymal duct to various treatments (see Brooks, $1976 \mathrm{~b}$ ). The activity of $\beta$-glucuronidase did not change in the caput or corpus epididymidis, but did decrease at 6 weeks after castration in the cauda epididymidis. However, exogenous androgen stimulated the enzyme activity in all the three segments and cyproterone acetate inhibited the stimulatory effects of the androgen. Thus $\beta$-glucuronidase would seem to be under androgenic control only in the cauda epididymidis. Surprisingly, the activity of $\beta$-glucuronidase decreases in all segments of the epididymis in intact mice treated with cyproterone acetate $(0.1$ $\mathrm{mg} /$ day for 15 days) (Rastogi, 1979). A similar discrepancy of response to different treatments was reported by Brooks, Hamilton \& Mallek (1974) who could not confirm the androgendependency of the accumulation of carnitine and glycerylphosphoryl choline in the epididymis of cyproterone acetate-treated intact rats. Like the localized androgen-dependency of $\beta$ glucuronidase, glucose-6-phosphate dehydrogenase seems to be under androgenic control only in the caput epididymidis of the mouse. In contrast, the histological appearance and the wet weight of all the three segments were found to be androgen-dependent as also in other species (e.g. rat: Brooks, 1976a, b).

The regional differences in the various responses to different treatments suggest that the epididymal segments may have different androgen thresholds and that various processes within a given segment of the epididymis can be influenced to differing degrees depending on the nature of the androgen (see also Vreeburg, 1975; Brooks, 1976b; Ganjam \& Amann, 1976; Jones, 1977).

It is known that spermatozoa are immotile and infertile in the caput, and motile and fertile in the cauda epididymidis. It therefore remains to be clarified whether the various biochemical processes in the epididymis are under androgenic control, what action they have on the functional maturation of spermatozoa, whether these phenomena are common to all mammals, and, finally, 
whether we can develop efficient contraceptive agents based on the prevention of the role of any of these processes in sperm maturation and maintenance.

Work supported by grants from the Ministry of Education (to R.K.R.) and National Research Council (finalized project "Biologia della Riproduzione").

\section{References}

Back, D.J., Glover, T.D., Shenton, J.C. \& Boyd, G.P. (1977) Some effects of cyproterone and cyproterone acetate on the reproductive physiology of the male rat. J. Reprod. Fert. 49, 237-243.

Brooks, D.E. (1976a) The activity and androgenic control of glycolytic enzymes in the epididymis and epididymal spermatozoa of the rat. Biochem. J. 156, $527-537$.

Brooks, D.E. (1976b) Control of glycolytic enzymes by androgens in the rat epididymis. J. Endocr. 71, 355365.

Brooks, D.E., Hamilton, D.W. \& Mallek, A.H. (1974) Carnitine and glycerylphosphorylcholine in the reproductive tract of the male rat. J. Reprod. Fert. $36,14 l-160$.

Djøseland, O., Hastings, C.D. \& Hansson, V. (1976) Androgen metabolism by rat epididymis. Metabolic conversion and nuclear binding after injection of $5 \alpha-$ androstane-3a-17 $\beta$-diol, in vivo. Steroids 28 , 585 596.

Fisher, R.A. (1954) Statistical Methods for Research Workers, 12th edn. Oliver and Boyd, London.

Ganjam, V.K. \& Amann, R.P. (1976) Steroids in fluids and sperm entering and leaving the bovine epididymis, epididymal tissue, and accessory sex gland secretions. Endocrinology 99, 1618-1630.

Hamilton, D.W. (1971) Steroid function in the mammalian epididymis. J. Reprod. Fert., Suppl. 13, 8997.

Hamilton, D.W. (1975) Structure and function of the epithelium lining of the ductuli efferentes, ductus epididymidis and ductus deferens in the rat. In Handbook of Physiology: Male Reproductive Physiology, Vol. 5, pp. 259-302. Eds D. W. Hamilton \& R. O. Greep. Williams \& Wilkins Co., Baltimore.

Jones, R. (1974) Absorption and secretion in the cauda epididymis of the rabbit and the effects of degenerating spermatozoa on epididymal plasma after castration. J. Endocr. 63, 157-165.

Jones, R. (1977) Effects of testosterone, testosterone metabolites and anti-androgens on the function of the male accessory glands in the rabbit and rat. $J$. Endocr. 74, 75-88.
Lowry, O.H., Rosebrough, N.J., Farr, A.L. \& Randall, R.J. (1951) Protein measurement with the Folin phenol reagent. J. biol. Chem. 193, 265-275.

Milone, M. \& Rastogi, R.K. (1976) Effect of testosterone upon the $\beta$-glucuronidase activity of some target tissues of the frog, Rana esculenta. J. Endocr. 70, 329-330.

Milone, M., Rastogi, R.K. \& Iela, L. (1975) Cyclic changes in the enzyme activity of the hypothalamohypophyseal system of the frog, Rana esculenta. Gen. Comp. Endocr. 26, 107-114.

Nag, S., Sarkar, D. \& Ghosh, J.J. (1977) Effect of cyproterone acetate on the proteinase activities in adult rat testis and epididymis. Biochem. Pharmacol. 26, 5-6.

Nicander, L. (1970) Morphological evidence of secretion and absorption in the epididymis. In Morphological Aspects of Andrology, Vol. 1, pp. 121-124. Eds A. F. Holstein \& E. Horstinam. Grosse Verlag, Berlin.

Orgebin-Crist, M.-C., Danzo, B.J. \& Davies, J. (1975) Endocrine control of the development and maintenance of sperm fertilizing ability in the epididymis. In Handbook of Physiology: Male Reproductive Physiology, Vol. 5, pp. 319-338. Eds D. W. Hamilton \& R. O. Greep. Williams \& Wilkins Co., Baltimore.

Prasad, M.R.N., Rajalakshmi, M. \& Reddy, P.R.K. (1972) Action of cyproterone acetate on male reproductive functions. Gynec. Invest. 2, 202-212.

Prasad, M.R.N., Rajalakshmi, M., Gupta, G. \& Karkun, T. (1973) Control of epididymal function. J. Reprod. Fert., Suppl. 18, 215-222.

Rastogi, R.K. (1979) A critical appraisal of the effects of antiandrogen, cyproterone acetate, on the epididymis in connection with fertility control in the male. J. Steroid Biochem. (in press).

Rastogi, R.K., Saxena, P.K. \& Iela, L. (1976) Histochemical localization of some hydroxysteroid dehydrogenases in the mouse epididymis. Hormone Res. 7, 43-48.

Vreeburg, J.T.M. (1975) Distribution of testosterone and $5 a$-dihydrotestosterone in rat epididymis and their concentrations in efferent duct fluid. J. Endocr. 67, 203-210. 